\title{
Asymmetric [4+2] Cycloaddition of Isochromene Acetals with Boronates
}<smiles></smiles>

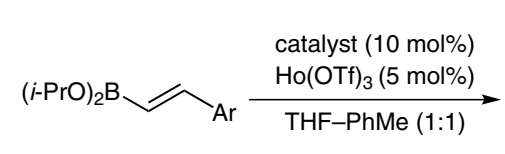<smiles></smiles>

$\mathrm{dr}>99: 1$

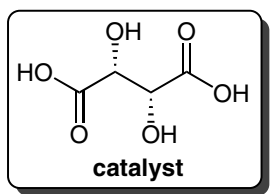

$$
\text { 事 }
$$

catalyst

Selected examples:<smiles>O=C[C@H]1c2ccccc2C=C[C@H]1c1ccccc1</smiles>

$76 \%$ yield $\mathrm{er}=95.5: 4.5$<smiles>O=CC1c2ccccc2C=CC1c1cccc(C(F)(F)F)c1</smiles>

$$
81 \% \text { yield }
$$
$\mathrm{er}=98.5: 1.5$<smiles>O=C[C@H]1c2cc(F)ccc2C=C[C@H]1c1ccccc1</smiles>

$81 \%$ yield er $=96.5: 3.5$<smiles>COc1ccc(C2C=Cc3ccccc3C2C=O)cc1</smiles>

$$
88 \% \text { yield }
$$
er $=97.5: 2.5$<smiles>O=C[C@H]1c2ccc(Cl)cc2C=CC1c1ccccc1</smiles><smiles>O=C[C@H]1c2cc3c(cc2C=C[C@H]1c1ccccc1)OCO3</smiles><smiles>O=CC1c2ccccc2C=CC1c1ccc2ccccc2c1</smiles>

$$
79 \% \text { yield }
$$
er $=95: 5$<smiles>O=C[C@H]1c2ccccc2C=CC1c1ccsc1</smiles>

\section{$91 \%$ yield} er $=90: 10$

The reaction of $\alpha$-substituted vinylboronate:

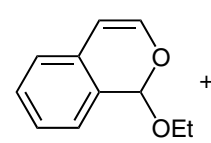<smiles>[18OH]C1=CC=C([18F])C1</smiles>

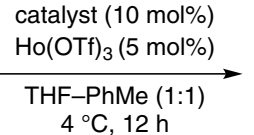

$4{ }^{\circ} \mathrm{C}, 12 \mathrm{~h}$

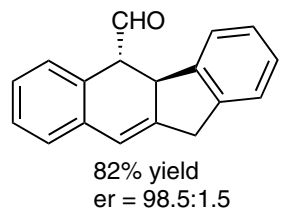

er $=98.5: 1.5$
Significance: The authors present the tartaric acid catalyzed asymmetric [4+2] cycloaddition of isochromene acetals with vinylboronates. A series of 1,2-dihydronaphthalene-1-carbaldehydes were prepared with excellent yields (up to 91\%), diastereo- (dr up to >99:1), and enantioselectivities (er up to $98.5: 1.5)$.
Comment: This method provides a facile access to chiral dihydronaphthalene building blocks that can be used to make important natural products and biological active compounds. Tartaric acid in combination with $\mathrm{Ho}(\mathrm{OTf})_{3}$ is highly effective for the reaction. 